\title{
BERMAIN LUDO KING UNTUK MENINGKATKAN KEMAMPUAN SOSIAL ANAK USIA DINI
}

\author{
Aldi Maulana ${ }^{1}$, Nita Yunitasari ${ }^{2}$, Risma Nurul Hikmah ${ }^{3}$, Rusmana ${ }^{4}$, Elfan \\ Fanhas Fatwa Khomaeny ${ }^{5}$ \\ ${ }^{1-5}$ Universitas Muhammdiyah Tasikmalaya \\ Email: aldimax001@gmail.com ${ }^{1}$, nitayunitasari19@gmail.com ${ }^{2}$, \\ rismanuru104@gmail.com ${ }^{3}$, panjulrtf98@ gmail.com ${ }^{4}$, elfan.fanhas@umtas.ac.id ${ }^{5}$
}

\begin{abstract}
ABSTRAK
Zaman yang semakin modern perkembangan teknologi di indonesia kian hari kian bertambah. Terbukti dengan banyaknya pengguna gadget dengan berbagai merk dan tipe tersebar luar diseluruh wilayah indosesia. Dengan kata lain ini bisa di sebut merubah aktivitas bermain anak pada saat ini yang lebih sering bermain permainan modern yang identik dengan penggunaan teknologi yang membuat anak lebih individual. Penggunanya tidak hanya orang dewasa saja akan tetapi anak usia dini pun ikut andil didalamnya, Penelitian ini menggunakan metode Deskriptif. Hasil kajian kami menunjukkan bahwa metode bermain dengan menggunakan media ludo king mampu memberikan pembelajaran untuk anak usia dini dalam aspek kemampuan sosial sejak dini. Dengan metode bermain ludo king akan melatih kemampuan sosial dan Emosi pada anak usia dini yang akan membentuk kemampuan sosial yang baik terhadap lingkungannya, maka dari itu sosial anak akan terlatih jika sudah dibiasakan pada saat usia dini. Anak anak usia dini yang sering bermain ludo king dengan otomatis sosialnya akan terlihat karena permainan ludo king ini melatih anak untuk berinteraksi dengan teman mainnya.
\end{abstract}

Kata Kuci: Ludo, Kemampuan Sosial, Anak Usia Dini

\begin{abstract}
In the increasingly modern era of technological developments in Indonesia increasingly increasing days. Proven by the many users of gadgets with various brands and types scattered outside the entire region of indosesia. In other words this can be called to change the activity of children playing at this time who more often play modern games that are identical with the use of technology that makes children more individual. Users are not only adults but also early childhood participate in it, This research uses Descriptive method. The results of our study indicate that the method of playing by using media ludo king able to provide learning for early childhood in the aspect of social skills from an early age. With the method of playing ludo king will train social skills and emotions in early childhood that will form a good social ability to the environment, therefore the child's social will be trained if it has been familiarized at an early age. Early young children who often play ludo king with automatic social will be seen because this game ludo king train children to interact with his playmates.
\end{abstract}

Keywords : Ludo, Social Ability, Early Childhood 


\section{PENDAHULUAN}

Di zaman yang semakin modern perkembangan teknologi di indonesia kian hari kian berkembang. Terbukti dengan banyaknya pengguna gedget dengan berbagai merk dan tipe yang tersebar di seluruh wilayah Indonesia. Penggunanya tidak hanya orang dewasa saja, akan tetapi anak usia dini pun telah menjadi pengguna yang mahir.

Menurut perusahaan survei eMarketer menyatakan bahwa, pengguna gadget di Indonesia meningka secara signifikan dan diprediksi merupakan 4 besar populasi pengguna gedget terbesar di dunia pada tahun 2016. Sebuah penelitian baru saja dikeluarkan American Association of Pediatrics (AAP) penelitian ini mengambil tajuk "Penggunaan Media Menjadi Dominan Dalam Keidupan Anak-Anak Jaman sekarang”. Media yang paling umum digunakan anak adalah gedget, jumlah anak anak yang menggunakan gedget meningkat hampir dua kali lipat (dari 38\% menjadi 72\%), dan semakin banyak bayi yang berusia 1 tahun : parentsindonesia.com,2013).

Masalah ini muncul karena orangtua memberikan kebebasan kepada anak tanpa adanya "pendampingan dialogis". Peran orangtua dalam pendampingan dialogis anak adalah tugas utama para orangtua, dengan pendampingan dialogis orangtua dapat mengontrol apa saja yang dilakukan dan dilihat anak supaya mencegah anak dari pengaruh negatif pemakaian gedget.
Penggunaan gadget anak usia dini menyita banyak perhatian dari berbagai kalangan, dari fakta di atas terlihat dari tahun ke tahun mengalami peningkatan signifikan. Tentu ini menjadi masalah besar bagi Negara kita selanjutnya. Anak-anak biasa mendapatkan gadget canggih dari kedua orang tuanya. Kedua orang tua sengaja memberikan gadget canggih kepada anaknya dengan tujuan, yang pertama untuk bermain games pada fitur-fitur yang telah disediakan pada gadget tersebut. Dibandingkan orang dewasa, anak-anak lebih cepat untuk menguasai gadget. Bahkan, orang tua mereka belum tentu dapat mengoperasikan gadget yang dimilikinya (Ismanto dan Onibala, 2015)

Penggunaan gadget dikalangan anak-anak semakin memprihatinkan dan tentu memiliki dampak negatif terhadap tumbuh kembang anak. Terlihat jelas anak-anak lebih cepat beradaptasi dengan teknologi yang ada. Sehingga anak-anak sering terlena dengan kecanggihan gadget dengan fitur-fitur yang tersedia di dalamnya. Anak-anak yang sering menggunakan gadget, seringkali lupa dengan lingkungan sekitarnya. Mereka lebih memilih bermain menggunakan gadget dari pada bermain bersama dengan teman-teman di lingkungan sekitar tempat tinggalnya. Sehingga interaksi sosial antara anak dengan masyarakat, lingkungan sekitar berkurang, bahkan semakin luntur (Ismanto dan Onibala, 2015). 
Aldi Maulana, Nita Yunitasari , Risma Nurul Hikmah, Rusmana, Elfan Fanhas Fatwa Khomaeny. BERMAIN LUDO KING UNTUK MENINGKATKAN KEMAMPUAN SOSIAL ANAK USIA DINI. Early Childhood Vol. 2 No. 2a, November 2018

\section{METODE PENELITIAN}

Penelitian ini menggunakan metode deskriptif, metode deskriptif Menurut Sumadi Suryabrata (2012:76) adalah penelitian yang bermaksud untuk membuat pencandraan (deskripsi) mengenai situasi-situasi atau kejadiankejadian. Dalam arti penelitian deskriptif itu adalah akumulasi data dasar dalam cara deskriptif semata-mata tidak perlu mencari atau menerangkan saling berhubungan, mentest hipotesis, membuat ramalan, atau mendapatkan makna dan implikasi walaupun penelitian yang bertujuan untuk menemukan hal-hal tersebut dapat mencakup juga metode-metode deskriptif.

Menurut Sugiono (2009: 29)

Metode Deskriptif adalah suatu metode yang berfungsi untuk mendeskripsikan atau memberi gambaran terhadap objek yang diteliti melalui data atau sampel yang telah terkumpul sebagaimana adanya, tanpa melakukan analisis dan membuat kesimpulan yang berlaku untuk umum.

Penelitian deskriptif dalam penelitian ini bertujuan untuk mendeskripsikan pemanfaatan gadget bagi anak usia dini di Indonesia

\section{HASIL DAN PEMBAHASAN}

\section{Pengertian Anak Usia Dini}

Ada beberapa pengertian atau definisi sehubungan dengan anak usia dini. Berikut ini akan kami sajikan sejumlah pengertian anak usia dini menurut para ahli dan karakteristiknya.
Pengertian anak usia dini adalah anak yang berada pada rentang usia 0-6 tahun (Undang-Undang Sisdiknas tahun 2003) dan sejumlah ahli pendidikan anak memberikan batasan 0-8 tahun.

Anak usia dini didefinisikan pula sebagai kelompok anak yang berada dalam proses pertumbuhan dan perkembangan yang bersifat unik. Mereka memiliki pola pertumbuhan dan perkembangan yang khusus sesuai dengan tingkat pertumbuhan dan perkembangannya (Mansur, 2005)

Pada masa tersebut merupakan masa emas (golden age), karena anak mengalami pertumbuhan dan perkembangan yang cukup pesat dan tidak tergantikan pada masa mendatang. Menurut banyak penelitian bidang neurologi ditemukan bahwa 50\% kecerdasan anak terbentuk pada kurun waktu 4 tahun pertama. Setelah usia 8 tahun, perkembangan otaknya mencapai $80 \%$ dan pada usia 18 tahun mencapai 100\% (Suyanto, 2005).

Mengacu pada Undang-undang Sisdiknas tahun 2003 pasal 1 ayat 14, upaya pembinaan yang ditujukan bagi anak usia 0-6 tahun tersebut dilakukan melalui Pendidikan Anak Usia Dini (PAUD). Pendidikan anak usia dini dapat dilaksanakan melalui pendidikan formal, nonformal dan informal. Pendidikan anak usia dini jalur formal berbentuk taman kanak-kanak (TK) dan Raudatul Athfal (RA) dan bentuk lain yang sederajat.

Pendidikan anak usia dini jalur nonformal berbentuk kelompok bermain (KB), taman penitipan anak (TPA), 
sedangkan PAUD pada jalur pendidikan informal berbentuk pendidikan keluarga atau pendidikan yang diselenggarakan oleh lingkungan seperti bina keluarga balita dan posyandu yang terintegrasi PAUD atau yang kita kenal dengan Satuan PAUD Sejenis (SPS). Berbagai pendidikan untuk anak usia dini jalur non formal terbagi atas tiga kelompok yaitu kelompok Taman Penitipan Anak (TPA) usia 0-6 tahun); Kelompok Bermain (KB) usia 2-6 tahun; kelompok SPS usia 0-6 tahun.

Dari uraian pengertian anak usia dini menurut para ahli di atas, dapat disimpulkan bahwa anak usia dini adalah anak yang berada pada rentang usia 0-6 tahun yang sedang mengalami pertumbuhan dan perkembangan yang sangat pesat, sehingga diperlukan stimulasi yang tepat agar dapat tumbuh dan berkembang dengan maksimal. Pemberian stimulasi tersebut melalui lingkungan keluarga, PAUD jalur non formal seperti tempat penitipan anak (TPA) atau kelompok bermain (KB) dan PAUD jalur formal seperti TK dan RA.

\section{Karakteristik Anak Usia Dini}

Karakteristik anak usia dini sangatlah unik, sebagaimana yang diungkapkan oleh Elfan Fanhas Fatwa Khomaeny : "Early Childhood is in the golden age of physical, emotional, social, and spiritual growth and development, and they have the characteristics of a great curiosity, unique personality, concrete thinking, egocentric, enjoys to fantasize and imagine, active and energetic, adventurous, learning many things using the body, has a short concentration, part of social beings, spontaneous, has a high learning spirit, lack of consideration, the most potential learning period, and easily frustrated. (Khomaeny, 2017:122).

Kartini Kartono dalam Saring Marsudi (2006: 6) mendiskripsikan karakteristik anak usia dini sebagai berikut :

1. Bersifat egoisantris naif

Anak memandang dunia luar dari pandangannya sendiri, sesuai dengan pengetahuan dan pemahamannya sendiri, dibatasi oleh perasaan dan pikirannya yang masih sempit. Maka anak belum mampu memahami arti sebenarnya dari suatu peristiwa dan belum mampu menempatkan diri ke dalam kehidupan orang lain.

2. Relasi sosial yang primitif

Relasi sosial yang primitif merupakan akibat dari sifat egoisantris naif. Ciri ini ditandai oleh kehidupan anak yang belum dapat memisahkan antara dirinya dengan keadaan lingkungan sosialnya. Anak pada masa ini hanya memiliki minat terhadap benda-benda atau peristiwa yang sesuai dengan daya fantasinya. Anak mulai membangun dunianya dengan khayalan dan keinginannya sendiri.

3. Kesatuan jasmani dan rohani yang tidak terpisahkan

Anak belum dapat membedakan antara dunia lahiriah dan batiniah. Isi lahiriah dan batiniah masih merupakan kesatuan yang utuh. 
Penghayatan anak terhadap sesuatu dikeluarkan atau diekspresikan secara bebas, spontan dan jujur baik dalam mimik, tingkah laku maupun pura-pura, anak mengekspresikannya secara terbuka karena itu janganlah mengajari atau membiasakan anak untuk tidak jujur.

4. Sikap hidup yang disiognomis

Anak bersikap fisiognomis terhadap dunianya, artinya secara langsung anak memberikan atribut atau sifat lahiriah atau sifat konkrit, nyata terhadap apa yang dihayatinya. Kondisi ini disebabkan karena pemahaman anak terhadap apa yang dihadapinya masih bersifat menyatu (totaliter) antara jasmani dan rohani. Anak belum dapat membedakan antara benda hidup dan benda mati. Segala sesuatu yang ada disekitarnya dianggap memiliki jiwa yang merupakan makhluk hidup yang memiliki jasmani dan rohani sekaligus, seperti dirinya sendiri.

Demikian pengertian anak usia dini menurut para ahli dan karakteristiknya. Memahami kedua aspek tersebut akan memudahkan kita dalam menentukan model atau strategi pembelajaran sesuai dengan tingkat umurnya.

\section{Keterampilan Sosial}

1. Pengertian Keterampilan Sosial Curtis (1988) menyatakan bahwa keterampilan sosial merupakan strategi yang digunakan ketika orang berusaha memulai ataupun mempertahankan suatu interaksi sosial. Kelly (dalam Ramdhani:1991) mengatakan bahwa keterampilan sosial adalah keterampilan yang diperoleh individu melalui proses belajar yang digunakan dalam berhubungan dengan lingkungannya dengan cara baik dan tepat. Hal ini bertujuan untuk mendapatkan pengukuh dari hubungan interpersonal yang dilakukan dan menolak hadirnya suatu keadaan yang tidak menyenangkan. Keterampilan sosial menurut Morgan (dalam Cartledge dan Milburn, 1995) adalah kemampuan untuk menyatakan dan berinteraksi secara positif dengan orang lain. Dari beberapa batasan yang dikemukakan ini, dapat disimpulkan bahwa keterampilan sosial adalah keterampilan atau strategi yang digunakan untuk memulai ataupun mempertahankan suatu hubungan yang positif dalam interaksi sosial, yang diperoleh melalui proses belajar dan bertujuan untuk mendapatkan hadiah atau penguat dalam hubungan interpersonal yang dilakukan.

2. Aspek Keterampilan Sosial Hasil penelitian yang dilakukan oleh Pusat Studi Pendidikan Anak Usia Dini UNY (2004) didapatkan hasil bahwa ada tiga aspek utama 
Aldi Maulana, Nita Yunitasari , Risma Nurul Hikmah, Rusmana, Elfan Fanhas Fatwa Khomaeny. BERMAIN LUDO KING UNTUK MENINGKATKAN KEMAMPUAN SOSIAL ANAK USIA DINI. Early Childhood Vol. 2 No. 2a, November 2018

dalam keterampilan sosial yang perlu ditanamkan dari sejak usia dini, yaitu:

1) Empati, meliputi :
a. penuh pengertian
b. tenggang rasa
c. kepedulian pada sesama

2) Afiliasi dan resolusi konflik, meliputi :

a. komunikasi dua arah/ hubungan antar pribadi

b. kerjasama

c. penyelesaian konflik

3) Mengembangkan kebiasaan positif, meliputi:
a. tata krama/kesopanan
b. kemandirian
c. tanggung jawab social

Ketiga aspek di atas mengacu kepada pendapat Curtis (1988), Brewer (2007), dan Depdiknas (2002) bahwa aspek keterampilan sosial yang dapat ditanamkan pada anak usia dini antara lain empati, tenggang rasa, kepedulian dengan sesama, kerja sama, penyelesaian konflik, kemandirian dan tanggung jawab sosial.

\section{Permainan Sosial}

Menurut Santrock (2007:217), permainan sosial adalah permainan yang melibatkan interaksi dengan teman sebaya. Menurut Morrison (2012:238) permainan sosial mempunyai banyak fungsi. Pertama, menjadi sarana untuk berinteraksi dengan orang lain dan mempelajari banyak keterampilan sosial, misalnya anak belajar berkompromi, menyelesaikan konflik. Kedua, permainan sosial menjadi sarana untuk mempraktikkan dan mengembangkan kemampuan bacatulis. Ketiga, permainan membantu mereka mengendalikan amarah. Keempat, membantu anak belajar cara berinteraksi sosial yang sangat penting dalam hidup.

Piaget dalam: Hartati (2005104) mengatakan bahwa permainan interaksi sosial datang dari bermacam-macam pemikiran yang rasional yang di tunjukkan oleh sifat egosentris untuk menonjolkan diri, di tandai oleh penguasaan, rasa saling membutuhkan dan kerjasama. Sedangkan menurut pendapat Catron dan Allen dalam Mutiah (2012:149) melalui bermain mendukung perkembangan sosialisasi seperti interaksi sosial, yakni interaksi dengan teman sebaya, orang dewasa, dan memecahkan konflik.

\section{LUDO KING}

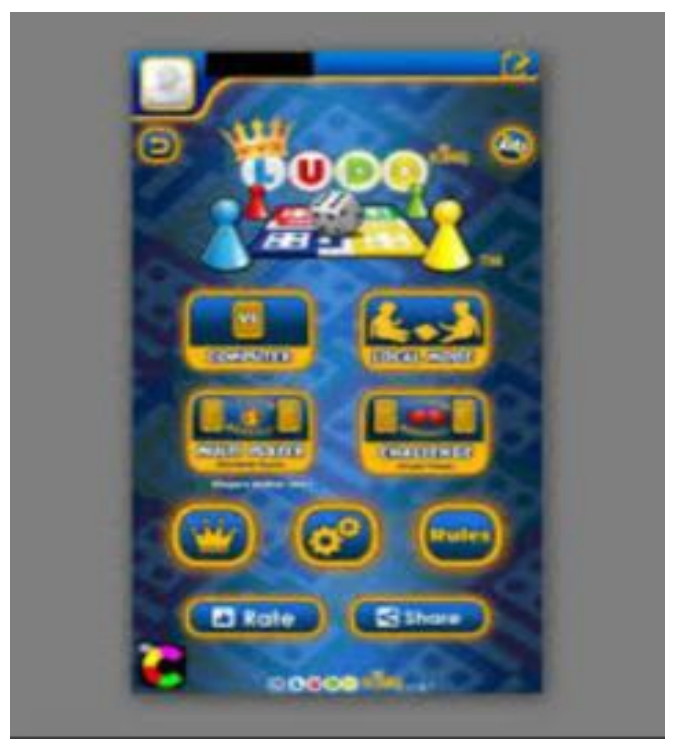

Ludo King merupakan salah satu jenis permainan sosial .Permainan ludo king adalah permainan papan dari spanyol yang sering di mainkan oleh 
Aldi Maulana, Nita Yunitasari, Risma Nurul Hikmah, Rusmana, Elfan Fanhas Fatwa Khomaeny. BERMAIN LUDO KING UNTUK MENINGKATKAN KEMAMPUAN SOSIAL ANAK USIA DINI. Early Childhood Vol. 2 No. 2a, November 2018

para pendeta kristen, Permainan Ludo king amat populer dari zaman dahulu hingga saat ini, hanya struktur permainannya saja yang sedikit bervariasi dan lebih modern. Ludo semakin berkembang di era teknologi digital.

\section{CARA BERMAIN LUDO KING}

Aturan main dalam permainan Ludo ini harus terdiri dari 2-4 orang yang harus mengatur strategi untuk berlomba memindahkan empat pion dengan menggunakan dadu. Pemenangnya merupakan pemain yang semua bidaknya paling cepat dipindahkan ke tujuan. Pemain juga memiliki opsi untuk memainkan game melawan komputer, melawan teman anda, atau bahkan melawan pemain dari seluruh dunia.

Saat memulai permainan, empat pion Ludo disusun pada rumah yang sesuai dengan warna yang terdapat di sudut papan.Untuk mengeluarkan pion Ludo dari rumah tersebut, setiap pemain harus mendapatkan hasil kocokan dadu dengan angka yang sama, yaitu angka '6'. Pemenang ditentukan dengan melihat siapa yang paling pertama meletakkan seluruh pion Ludo ke titik akhir.

Berikut adalah tahapan tata cara bermain ludo king :

1. Cari Teman minimal 1 orang dan maksimal 4 orang untuk diajak bermain Bersama;
2. Untuk bisa mengeluarkan pion, anda harus mengocok dadu sampai keluar angka 6;

3. Jalankan pion tersebut jika sudah keluar, sesuai dengan angka yang tertera pada dadu hasil kocokan;

4. Anda bisa memasukan pion lawan ke tempat asalnya, dengan cara anda menginjak di kotak yang sama;

5. Di dalam kotak ludo ada zona yang bergambar bintang, disana anda bisa selamat jika anda berada di kotak itu. Anda juga bisa diam di kotak tempat dimana teman bermain anda untuk mengamankan pion anda;

6. Untuk menyelesaikan permainan, anda harus sampai finish dengan syarat mengelilingi semua kotak ludo dan kembali ke daerah anda.

Dari beberapa uraian di atas, permainan Ludo King merupakan jenis permainan sosial, dimana anak dapat belajar tentang berkomunikasi, sosialisasi dengan teman sebayanya dan mengembangkan kecakapan sosial anak sehingga melalui permainan Ludo King dapat meningkatkan interaksi sosial anak.

Permainan Ludo King
dimainkan secara bersama-sama, Kelebihan dari permainan Ludo King, yaitu mengutamakan interaksi sosial dan melatih emosi serta moral anak, karena dalam proses bermain anak dituntut untuk bermain jujur, adil dan penuh tanggung jawab. Permainan Ludo King memiliki nilai-nilai luhur dan 
pesan moral, seperti: nilai-nilai kebersamaan, kejujuran, tanggung jawab, lapang dada (kalau kalah), dorongan berprestasi, menghargai orang lain, keakraban, toleransi, aktif, kreatif, kemandirian, kepedulian terhadap lingkungan sekitar, solidaritas, sportivitas, dan taat pada aturan, jika pemain dapat menikmati permainan dan peraturan permainan pun dapat disesuaikan dengan kesepakatan para pemain.

\section{LUDO KING UNTUK MELATIH SOSIAL}

Dengan Ludo King anak akan lebih berjiwa sosial dan Emosi nya yang stabil, karena anak dibiasakan untuk berinteraksi sembari bermain Ludo King Bersama teman temannya, maka dari itu sosial anak akan terlatih jika sudah dibiasakan pada saat usia dini. Anak anak yang sering bermain ludo king dengan otomatis sosial anak akan terlihat karena dari kecil sudah dilatih untuk berinteraksi dengan teman mainnya .

Karena dengan Ludo King, anak akan berjiwa Sosial Tinggi dan Bisa Mengatur Emosi .

a. Berjiwa Sosial

Berjiwa Sosial adalah orang-orang yang senang bergaul dan memiliki empati atau pemahaman yang besar terhadap kesulitan dan keberatan orang lain dan lingkungannya. Orang Yang Berjiwa Sosial cenderung berusaha sekuat mungkin agar dirinya bisa diterima oleh orang lain dan lingkungannya.
Menurutnya kebahagiaan hidup akan tercipta apabila orang lain dan lingkungan menerimanya dengan baik. Dengan penerimaan itu, dia akan berusaha membantu orang lain yang kesulitan atau berbagi akan hal-hal yang dimiliki, dikuasai dan diketahuinya kepada orang lain.

Orang Yang Berjiwa selalu menjaga hubungannya dengan orang lain, misalnya dengan saudara, keluarga, teman bahkan rekan kerjanya. Demikian pula dalam hidup berkeluarga, biasanya Orang Yang Berjiwa Sosial dicintai istri, suami dan anak-anaknya bahkan keluarga besarnya. Hal-hal yang dibagi kepada orang-orang di sekitarnya tidak selalu dalam bentuk materi, bisa berupa perhatian atau nasihat serta hal lainnya yang diperlukan oleh orang lain.

b. Emosi

Emosi adalah perasaan intens yang ditujukan kepada seseorang atau sesuatu. Emosi adalah reaksi terhadap seseorang atau kejadian. Emosi dapat ditunjukkan ketika merasa senang mengenai sesuatu, marah kepada seseorang, ataupun takut terhadap sesuatu.

\section{SIMPULAN}

Metode bermain dengan menggunakan media ludo king mampu memberikan pembelajaran untuk anak usia dini dalam aspek kemampuan sosial sejak dini. Dengan metode bermain ludo king akan melatih kemampuan sosial dan 
Aldi Maulana, Nita Yunitasari , Risma Nurul Hikmah, Rusmana, Elfan Fanhas Fatwa Khomaeny. BERMAIN LUDO KING UNTUK MENINGKATKAN KEMAMPUAN SOSIAL ANAK USIA DINI. Early Childhood Vol. 2 No. 2a, November 2018

Emosi pada anak usia dini yang akan membentuk kemampuan sosial yang baik terhadap lingkungannya, maka dari itu sosial anak akan terlatih jika sudah dibiasakan pada saat usia dini. Anak anak usia dini yang sering bermain ludo king dengan otomatis akan berjiwa sosial dan sosialnya akan terlihat karena permainan ludo king ini melatih anak untuk berinteraksi dengan teman mainnya .

\section{DAFTAR PUSTAKA}

Cartledge, G. \& Millburn, J. F. 1995. Teaching Social Skills to Children \&Youth. Innovative Aproach, 3rd ed. Massachussets: Allyn \& Bacon.

Hartati, Sofia. 2005. Perkembangan Belajar Anak Usia Dini. Jakarta: Departemen Pendidikan Nasional.

Khomaeny, Elfan Fanhas Fatwa dan Hudha , Nandhini Anggarasari. Introducing the Creator To The Early Childhood. Proceeding The 1st International Conference on Education, Universitas Pendidikan Indonesia Kampus Tasikmalaya, December 21-22, 2017 ISBN. 978-602-60624-2-0.

Marsudi Saring. 2006. Permasalahan Dan Bimbingan di Taman Kanak-Kanak. FKIP UMS.
Manumpil, Beauty; Ismato, Yudi; Onibala, Franly. Hubungan penggunaan Gadget dengan tingkat prestasi siswa di SMA N 9 Manado. Ejournal keperawatan, Vol. 3 No. 2 April Tahun 2015.

Morrison. 2012. Dasar-dasar Pendidikan Anak Usia Dini. Jakarta : PT Indeks.

Mutiah, Diana. 2012. Psikologi Bermain Anak Usia Dini. Jakarta: Kencana Prenada Media Group.

Ramdhani, N. 1991. Standardisasi skala tingkah laku sosial. Laporan Penelitian.. Yogyakarta : Fakultas Psikologi UGM.

Suryabrata, Sumadi. 2012. Metodologi Penelitian. Jakarta: Rajagrafindo Persada.

Sugiyono, 2009, Metode Penelitian Kuantitatif, Kualitatif dan $R \& D$, Bandung : Alfabeta.

Mansur. 2005. Pendidikan Anak Usia Dini Dalam Islam, (Yogyakarta: Pustaka Pelajar).

Suyanto, 2005. Konsep Dasar Anak Usia Dini : Jakarta : Departemen Pendidikan Nasional. 
Aldi Maulana, Nita Yunitasari , Risma Nurul Hikmah, Rusmana, Elfan Fanhas Fatwa Khomaeny. BERMAIN LUDO KING UNTUK MENINGKATKAN KEMAMPUAN SOSIAL ANAK USIA DINI. Early Childhood Vol. 2 No. 2a, November 2018

Santrock. 2007. Perkembangan Anak Edisi 7. Jakarta : PT Gelora Aksara Pratama.

http://www.kompasiana.com/labolong/s tatistik-internet-di-indonesia di akses pada tanggal 10 Juli 2018

http://www.duniashowbiz.com/2018/01/ 03/346/ di akses pada tanggal 10 Juli 2018

http://tekno.liputan6.com/read/800204/i ni-10-negara-denganpenjualan-smartphoneterbanyak-indonesia diakses pada tanggal 10 Juli 2018 